\title{
Some translation peculiarities of economic texts (on the basis of economic texts translation form English into Ukrainian)

\author{
Olesia Borysova*
}

Ukraine, Kyiv, the Taras Shevchenko National University of Kyiv, the Institute of Philology, Shevchenko blv.14

Email address: bacchus@ukr.net

Keywords: economic texts, translation, translation transformations, terms, metaphors, acronyms.

\begin{abstract}
This paper deals with some translation peculiarities of economic texts and analyses the ways of rendering economic terms, metaphors and phraseological units, acronyms and names of organizations in the economic texts. It describes translation transformations used in the process of rendering the above mentioned lexical units.
\end{abstract}

\section{INTRODUCTION}

Taking into account the modern changes of the world and current political situations the economic texts are becoming more and more popular among both specialists and ordinary citizens. The interest is constantly growing in the following spheres: finance, credits, industry, and currency. In order to solve global financial and economic problems many economists combine their efforts in collaboration creating anticrisis programs and conventions.

The topicality of this article is based on the increasing interest in the special translation theory of economic translation, because it is still not researched properly and constantly causes some difficulties.

The practical value of this article is in the ability to use its materials and conclusions both in the economic texts translation process and in the preparing lectures for the special course "Economic Texts Translation".

The aim of the article is to reveal some peculiarities of economic texts translation from English into Ukrainian. When we speak about economic texts, we mean publications (texts) on economic issues.

Therefore, our research is based on the material of publicist texts from the prominent economic publishers.

In order to reach the aim mentioned above, it is necessary to fulfill the following tasks:

- to find out and analyze language translation peculiarities of the economic texts in the process of translating from English into Ukrainian;

- to research most frequent translation transformations and approaches used in overcoming translation difficulties in economic texts.

Having analyzed economic texts, we came to the following lexical peculiarities:

1) the research materials are full of economic vocabulary the biggest part of which is terms;

2) there are many metaphors and phraseological units which prevail in the English economic texts more than in Ukrainian ones;

3 ) wide usage of the acronyms and titles.

On the whole, the above mentioned aspects of economic texts translation are worthy of special attention in the process of translation, so they will be paid more attention.

First of all, there are some language peculiarities that have much influence on the result of translation, so we want to point out the role of terms and special economic vocabulary [1]. 


\section{TERMS AND SPECIAL ECONOMIC VOCABULARY TRANSLATION AND PROBLEMS IN RENDERING COMMON VOCABULARY IN ECONOMIC TEXTS.}

Some economic terms in English-Ukrainian translation has dictionary equivalents, for example: industry - промисловість, manufacturing output - об'єми промислового виробництва, capability- продуктивність (ukr). Other economic terms strongly need the context to be translated, for example: Some securities on bank books are starting to recover in value. - Деякі иінні папери на банківських депозитах починають відновлюватись у ціні (ukr) [2].

This sentence consists of terms and words from the special economic vocabulary: securityбезпека, охорона, застава, поручитель, а в множині - цінні папери; to recover- повертати собі, видужувати, надолужувати, стягувати судовим порядком (ukr). Obviously, to choose the right equivalent we need at least the context of the sentence and the knowledge of the economic field the term belongs to.

Our research also reveals that in the Ukrainian language there are many terms which were created as the result of calque (literal translation), for example: liquid funds- ліквідні фонди, reserve currency- резервна валюта, hedge funds-хеджеві фонди (ukr). Taking into account that this tendency is still in trend now, we can consider the calque (literal translation) as another way of terms and words from special vocabulary translation.

The usage of transliteration and transcription is also widespread in the translation of economic texts, for instance: export-эксnорт, capital-капітал, industrial-індустріальний. Transcription is more frequent in the titles or proper names rendering: Kaoru Yosano - Kaopy Ёсано, Wall Street Journal - Уолл-стрит джсоннал (ukr).

It is also worth mentioning, that in the economic articles there are many words from common vocabulary, which can be divided in to two groups: 1) common words which don't cause problems in translation (work, company, office); 2) words the meanings of which differ from common usage (to run- замість значення «біжати» в економічних текстах це слово набуває таких значень: «керувати (фірмою)», «одночасно знімати гроші з рахунків банку (про вкладників)», prospect, n- окрім значення «перспектива», «плани на майбутнє», в сфері маркетингу це слово набуває ще й значення «потенційний клієнт», currency appreciationпідвищення курсу валюти, purchasing power- купівельна спроможність) (ukr).

In general, as it is shown in the examples, the knowledge of the difference in lexical meanings, which is depend on the economic field the word belongs to is vital.

\section{TRANSLATION OF THE METAPHORS AND PHRASEOLOGICAL UNITS IN THE ECONOMIC TEXTS.}

The problems in translating the phraseological units in the economic texts are based on the fact that not every dictionary can predict all its usage possibilities in the context [3]. For example, it is possible to translate $d o g$ and pony show as: «зробити промову», «показати номер», in the economic text as usually it means «презентаиія товару, на якій використовують багато візуальних ефектів» (ukr). That is why such phraseological units are translated with the help of description transformation, addition (extension) transformation.

Also while translating phraseological units we have to follow stylistic and genre homogeneity with the phraseological unit of source language [4].

This statement, in our opinion, is also valid to the metaphor translation: A directive of the European Union stipulating that all fuel at the pump should contain 5.75 percent biofuel by 2010 encouraged many large corporations to jump into the market.- Директива Євросоюзу, яка передбачає, щзо до 2010 паливо в бензонасосі має містити 5.75 відсотків біопалива, мотивує багато великих корпорацій стрімко з'явитися на иьому ринку (ukr) [2].

In this sentence in order to follow the stylistic and genre homogeneity the metaphor to jump into the market was rendered not as «вскочити» (which has more negative connotation and is more informal), but the transformations of addition (extension) were used. 
The difficulties in metaphor and phraseological unit translation are the following.

1. If this text is translated by the economists who know the language and the subject (they understand the topic they translate), but they are not experienced in translating metaphors and/or phraseological units, in this case there will be word by word translation, for example: loan shark1) "кредитна акула", this version of translation is so widespread that it has been already in the dictionary; 2) лихвар (юридична або фізична особа, щзо видає кредити під проценти, щзо перевищують встановлений законом максимум) (ukr).

2. If this text is translated by the licensed translator the rendering of the metaphor and phraseological unit will be done perfectly but the main sense of the sentence could vanish.

It is also worth mentioning that metaphor and phraseological unit are more frequent in the English publisistics than in Ukrainian.

\section{TRANSLATION OF THE ACRONYMS AND NAMES OF ORGANIZATIONS.}

The economic texts are characterized by acronyms, most of which are used in economic texts and documents, for example: IMF - International Monetary Fund-Міжнародний валютний фонд (МВФ), Gross Domestic Product- валовий внутрішній продукт (ВВП) (ukr). As a rule, the acronyms mentioned above are widespread in the economic field, so they could be presented in the economic oriented dictionaries (the usage of which is strongly recommended for translating special texts).

Furthermore, today we have many new acronyms, which are not mentioned in the dictionaries. Sometimes we deal with new ones, and sometimes these acronyms are created in order to use time and place wisely. In this case, first of all the translator should decide to which word each letter of the acronym refers and then he or she should translate the whole word combination, then the translator should make it short (create his own acronym in the target language), for example:

It's only recently that computer hardware and software of the type needed to run enterprise resource planning (ERP) have become powerful enough to extend beyond the boundaries of a single firm. - Лиме з недавнього часу комп'ютерне забезпечення та програми, необхідні для управління плануванням ресурсів підприємства (ПРП), стали досить потужними, щоб поширюватися за межі фірми (ukr) [5].

There are some acronyms, which are usually transliterated. As a rule, it's the names of companies and systems created a long time ago, for instance: SWIFT-Society for Worldwide Interbank Financial Telecomunications.- Міжнародна міжбанківська система передачі інформації та здійснення платежів (СВIФT) (ukr).

Some of the acronyms have many different meanings even in one sphere (in our case in the economics): SCM -1) supply chain management (управління ланцюгом поставок)- на рівні бізнес структур, 2) Subsidies and Countervailing Measures (cубсидї та компенсаційні міри)- у сфері державного фінансування. In such cases the knowledge of the context is of vital importance: SCM (Supply chain management) oversees the enterprise relationships in order to get the information necessary to run the business... -Відділ постачання контролює зв'язки підприємства с метою отримання інформації, необхідної для ведення бізнесу (ukr) [5].

\section{CONCLUSION}

In conclusion, in the process of translating acronyms it is recommended to consult with the search engines and look up in the dictionary in order to realize the actual meaning of the acronym.

To sum up, it is very important not only to know translation transformations and be experienced in its usage, but also to be informed in the subject of translation (the knowledge of economic processes and notions). 


\section{References}

[1] Komissarov V.N., General Theory of Translation,Moscow: CheRo, 2000.

[2] Borysova O.V., Practice of Translation From the Second Language (English): Tutorial for students of the 4-th year / scientific editor Prof. V.I. Karaban, Kyiv, Osvita Ukraini, 2010.

[3] Alimov V.V., Theory of Translation. Translation in the Sphere of professional communication: Tutorial, Moscow, KomKniha, 2006.

[4] Komissarov V.N., Theory of Translation (linguistic aspects): Text-book for institutes and departments of foreign languages, Moscow, Vissha Shcola,1990.

[5] The International Journal of Logistics Management, 2003- Information on http://www.deepdyve.com/browse/journals/the-international-journal-of-logistics-management 